\title{
人文地理教育の調查一現狀と希望一-
}

\section{熊”谷金 男}

6, 3 制の實施に次いで新しい满想之希然に充ちて 新 制高校が發足した。1 學年は一般社會科の必 修，2，3 學年は時事問題，西洋史，東洋史，人文地理と分科してそれぞれ選擇科となつた。待ちあぐ

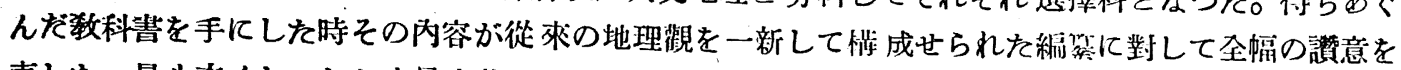
表した。最も古くしてしかも最も若くしい地理の發達には，また學的にも，䡈育的にもなやみが多かつ

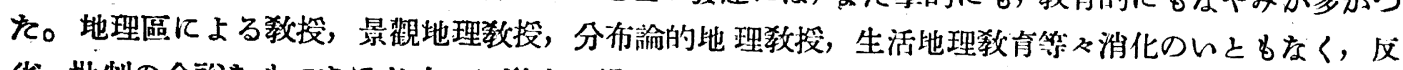

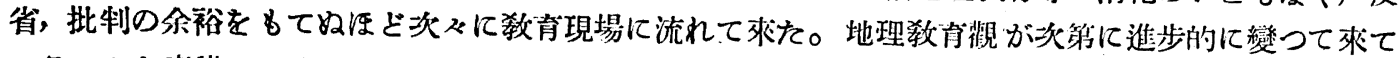
いるてとを意識しても，割り切れぬものを胸底に殘してをゃみつがけて来たのであつた。さればてそ 人文地理を。手にしたときは们となく救はれた感じを抱いたのである。摴入せられた地滴, 圖表, 數喠 をど若き學徒, 若き教育者の勞作が探錄されているではをいか, 生き生きとした新鮮味を教科書から 感得せられたのるての點が大をな力を持つているのではあるまいか。㸚青現場の管作を身近に捉えな

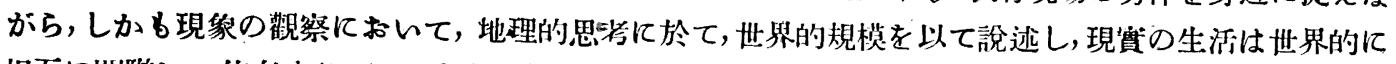

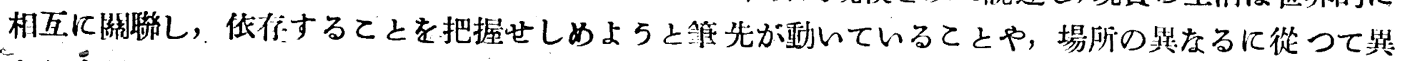

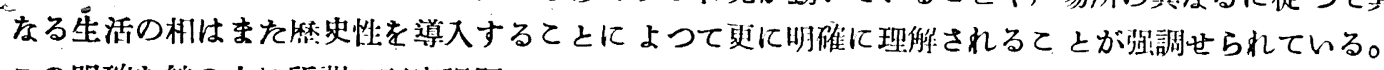
ての明確な線の上に質問と研究課題が設定されていよいよ其休的に生徒自身に人文地理の興味之研究 の方法とを暗示している。斯の如く一新せられた呚科書に街躍しながら生徒の現状を省みたとを，そ てには多くの問題がてろがつている。革新の人文地理と生徒との距離, 迩擇制と教室の問題, 研究の 施設と研究資料の問題，現場のなやみは果しなく縓く。「新测高校の人文地理」と銘打つた参考書が街

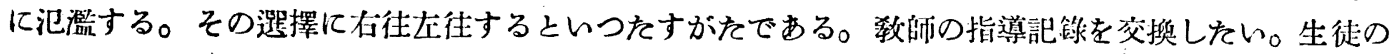
研究を交流したい。てれが互いの切實をる願いであり，編集室でもてれが知りたい。たしかなる步

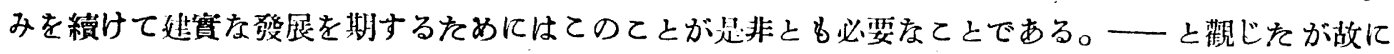

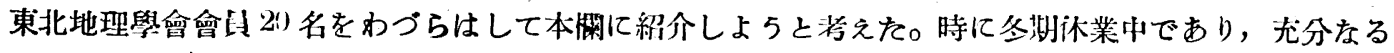
まとめの期間を得なかつたなどのために全貝の報告を得なかつたっいづれる各ふの立場から思䇣さ れ，体驗せられた盗重な報告である。各位に對して謝意を表し，なやみの解沈へと努力して人文地理 が素直に發展するてとを裤して叛まない。

問合世事項

I 教科書に對する意見 (批制, 腑㘹)

II 全校教科編成上探用該當事項に○印をつける 1. 純然をる造摆制 2. 其通必修制 3. 其の他 1 生徒の研究

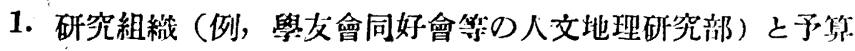

2.これまで研究した題目

3. 發表方法

IV 新年度 (24: 年度の構想)

以下解答到着順に御紹介する。

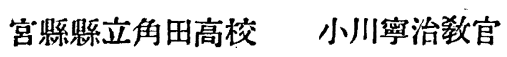

I 從來に見られなかつた新しい哜科费として難解だ とか色々の批評はむるが，私としてはよくできていると 思ろ。我々は之に批評を加之ることも結構であるが先づ 呚科書として利用して見ることが第一である。その利用 は我々の力にある事, 利用守る力が泛し!して敎科書を 云々することはどどうかと思う。殊に筫問, 研究楃が相 當批制されるようでむるが，之も生徒にそのま亦した
のでは無理, 先生と生徒とが一体となつて研究すればよ から弓。又質問研究を全部やらうとするから無理が生げ る。希望としては「飲み物」の項にコーヒー,ココアな ど我々の生涯に關係のないものが出ているのはどうが 思う。嗜好品としてならむしつ「煙草」がほしかつた。 む万一年使用してから批制したいと思万。

II 學年本までは共通必修制, 但し 9 月以降は 1 組が 共通必修，他の組は西洋史との選擇制なり。 
1. 研究組織なし。

2. 特にい弓べきことなし。

一部生㺼が「ラジオ，新等を通じてみたた鄉上の 文比性について」全校生徒に墢表方。

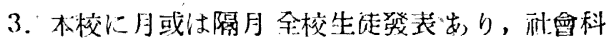
は己を利用していふ。

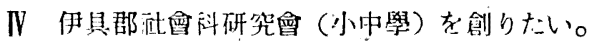
生走の人文地理研究クラブを創りたい一現在その母体 となるものが齐る。

地理に關した展覽會を定期的に数回開きたい。

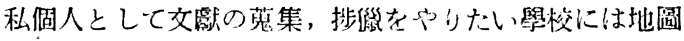
皆舆河完搠完たい。

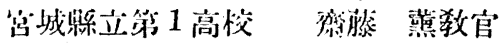

1 附錄として資料,統計を載せられたい。統計は10年 前のもののみによつていることは遺憾で多る。

啠問 研究訆題が多過ぎる。重要なもの 2,3 題, 数 科䡒に出て來る地名を集錄した世界地圖を付せら於た い。

㽞汭不鮮明なり。

叙述の本明化をのぞ生。

概してよく彗けている゙。

II 共涌必修制

】1、社會クラフ，予算 1500 圆

2. 新憲法の研究

敉科書中の研究課題

花業復與の進度

3. ポスター展監會

常特揭示䜿蒙

討論雪

IV 從來社會クラブは社會科に無關係で獨自の「社會 研究のクラブ」としてのみ墈、ていたがこれを活用した wo

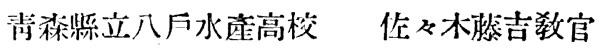

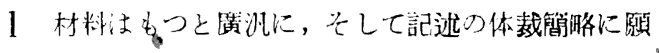
1. $2=6$ :

II 共通必修制

11. 好きな者のグループでやつている。

2. 鄉士の衣食住の各方面の特異性 年中行事

3. 學級及び討議式を加味して行ら場合と，學校 生徒職員全員の中で發表する場合どあり。

IV 野外調查を多くすること。

一部面をや〉深くはいる調べ方, 考え方を来いたい。

\section{宮城黝塩釜方立高校伊藤博夫呚官}

I 内谷は高等普通敉育に我分一方的な感じがあ り，普通性がない。むつとも2然ができたらどらかわか

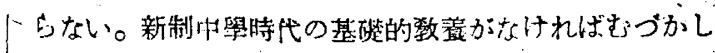
Wo

II 共酒必繁制

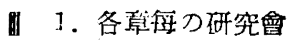

2. 各垶全部

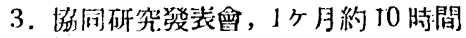

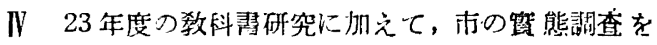
行了。

\section{秋田橴立横手美入野高校，鈴木雄喜敎官}

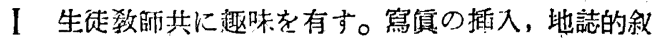
速をのぞも。

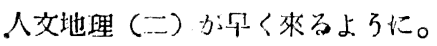

II 共通必修制

II 1.同好曾を研究中，予算なし

2. 橫手㧧地集落の研究

- 数科書の留問研究課題の項

3.リボート

N 3 年生は人文地理 (二) 2 年は同 (一)

校外授業と併行的に行引。

鄉士研究を中心に外國の地誌を授業してみたい。

山形縣立第 4 高校 小野沾次郎数官

I 数科专の内谷，叙述等は今迄に見巨れない漸新な ものがあるか（a）項目をつけ內谷を明示寸ること,(b)

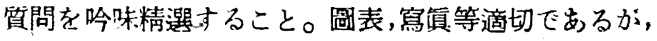
紙留のため不鮮明，下欄の問無理なるの岕り。

II 共通必修制

圈 1 , 校友會鄉土部 (人文地理を主とし, 歷史關系 を含むが末だ分科せげ）…小生部長

予算は 7000 圓

2. 平淸水の陶器

天童町，米澤市，寒河汇町 (考占學) 等を見學調 查寸。

3. 各自の感想, 要項記錄（册子發行の予定）

NV人文地理を中心とした組織的研究調查（秋野の開 拓, 家屋地理)。

\section{仙营市私立䅅和學園女子高校 結城清敉官}

I 人文地理数料書は極めて妥當にして活用の如何に よつては其成果著しきものと思料す。但し鄉士との關係 を工夫する創意を必要と認む。

II 共通必修制

1. 广厼

2. 特に主題を持ちて研究せざるも，2，3掛鲴其 他の地圖を生徒をして共同製作せしめた。

3. 授業中適時指示に基づく研究 發表を行 5 以外 特に他の發表法を探り得げ。

NN 本胙は人文地理の呚授上に一段の工夫をこらし其 
の徹底を期すると共に文化國家上その面目を發揮するよ う努力したい。

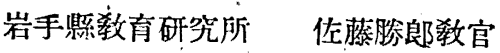

I 生活を基盤とした學習をする比よい敉科書だと よそこんでいる。2 然の完結を希望す。

II 一以下は 23 年度呚育研究所に勤㘯のため, 記载不 能，現場に出て墈きたいと思つている。

\section{岩手縣立花卷第 1 高校佐々木久藏呚官}

I なし

II 3 その他を探用

1. 校友會社會第一部, 予算 3180 圓

2. 稗貫郡の米作, 花参の地形, 岩手縣の地名, 花

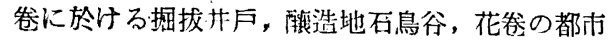
計剧

3. 每月例會開催,年一回校內發表會, プリントに して研究物を綜合（2月上旬当來の新定，目下゙フ。
リント屋に俄賴中）

IV 個人研究の推進

䔰城縣立仙裳第 2 女子高校高 橋策一郎呚官

I 1. 全体として從來の教課毒上りも優れていると 思万が內谷の記載をもつとくだけてほしい。

2. 留問，課題の中には程度の高すぎるものが女 る。

3. 地圖, 插繪, 印制が不鮮明で㚣る。

4.この呚科凄に相喕する立派な地圆帳が汪しい

II 共通必修制

011. 生徒に自由題目で研究調查させてレポート提 出, 自治會文化科學部の有志か人交地理を研究す る女化科學部予算 9950 員

2. 各人によつて翼なるが宮诚縣に 關する題目が 最も多小。

3. 學級每發表せしめ, 批制討議せしめふ。

IV 野外調查を多くとり入れ，個人指導を行いたい。 （宮城縣敎育研究所） 